\title{
The Impact of Market Value Added to Shareholder Value: Evidence from Indonesia Firms.
}

\author{
Rio Dhani Laksana ${ }^{1 *}$, Viviana Mayasari ${ }^{2}$ \\ ${ }^{12}$ Faculty Economics and Business, Universitas Jenderal Soedirman, Indonesia
}

\begin{abstract}
Presently financial experts developed the new concept as a value-based measure of performance in the creation of shareholder value. Market value for shareholders are among the most important goals of firms and owners The purpose of this study is to obtain empirical evidence of Economic Value Added (EVA) affects shareholder value by the method of Market Value Added (MVA) The research using non-financial companies listed on the Stock Exchange from 2013-2017. The result is support that the Economic Value Added (EVA) positive effect on shareholder value or in other words, the higher EVA is the higher shareholder value. The larger the company greater shareholder value and Leverage negative effect on shareholder value as measured using the method of MVA.
\end{abstract}

\section{Introduction}

In the recent years, value-based measures have been received a lot of attention during the last two decades, value-based economic value added (EVA) is paid close attention by several accounting, business and nance researchers, corporate professionals, and consultant firms and thus they accept the limitations of traditional measures of performance (Bhasin, 2013). Thus, many scholars criticize traditional measures. Their findings suggest that traditional measures are not proper guidance to make a strategic decision (Laksana et al., 2017). Therefore, we can say that traditional measures still play an important role as instruments for assessing the economic and accounting performance of firms. However, traditional measures only provide information from judgments on past performance (Pinto and Santos, 2011). The purpose of this study is to investigate the impact of profitability on market MVA.

EVA is an indicator of the value creation of an investment. Positive EVA indicates the company managed to create value for the owners of the company, in line to maximize firm value (Utama, 1997). EVA focuses on managerial effectiveness in a given year by estimating the economic profit obtained from the company's business activities in one year. EVA measures the extent to which the company has increasing value for shareholders (shareholder value). Therefore, if the manager focuses on the EVA, this can ensure

* Corresponding author: riodhani@unsoed.ac.id 
consistent operating managers in maximizing shareholder wealth. Positive EVA indicates that the company succeeded in creating shareholder value. Shareholder value is measured in two ways, namely Market Value Added (MVA) and the Created Shareholder Value (CSV). MVA was introduced to overcome weaknesses or criticisms of EVA. For example, EVA is not counting the opportunity to grow attached to a company's investment decisions (Ramezani, Soenen and Jung, 2002).

There is a relationship between EVA and shareholder value. If viewed the relationship between EVA and MVA, it can be said that the company has a history of negative EVA, will have the possibility that the MVA value of the company will also be negative, and vice versa if the company has a history of positive EVA, will have the possibility that the MVA value of the company will also be positive.

Based on the above explanation, the researchers wanted to test the effect of EVA on shareholder value, where shareholder value is measured by the method of MVA. The methods are used to address and improve the methods of EVA as a measurement of value creation for shareholders. The purpose of this study was to obtain empirical evidence regarding the effect of EVA on shareholder value, through the two methods is the method of MVA. The results of the research will further clarify the relationship between EVA with shareholder value as measured through the method of MVA so it can be used as a benchmark in measuring corporate performance and value creation for shareholders.

\section{Figures and tables}

\subsection{Population and Sample}

The population in this study were the companies listed in Indonesia Stock Exchange (BEI). The study sample was non-financial companies listed in the population. The sampling method is purposive sampling, with sample criteria are as follows: Non-financial companies listed on the Stock Exchange during the last five years, starting from 2013 to 2017 and there is every year, The company that publishes the annual report ended December 31, during the period of observation, Financial statements denominated in rupiah, Having all the data used to calculate the variables that are the focus of this study.

\subsection{Data Collection}

The data used in this study are secondary data, ie data collected from a database of IDX's Annual Report on the Stock Exchange-listed companies available on Indonesian Capital Market Directory (ICMD)

\subsection{Operational Definitions}

\subsubsection{Economic Value Added (EVA)}

EVA is an independent variable in this study. EVA describes the company's residual income after deducting the overall cost of capital. In contrast to traditional accounting performance measures (such as ROE), EVA tries to measure the added value generated in a company, by reducing the cost of capital (cost of capital) incurred as a result of investments made. In other words, EVA measures the extent to which the company has increased shareholder value. EVA approach developed by the institute of management consultants 
from the United States named Stern Stewart Management Services in the mid-1990s. The operational definition of EVA is as follows:

NOPAT $=$ EBIT $(1-$ Tax $)$

$$
\text { EVA }=\text { NOPAT - Capital Costs }
$$

Cost of Capital $=$ Total Invested Capital $x$ WACC

$\mathrm{WACC}=($ cost of debt $\mathrm{x}$ proportion of debt $)+(\mathrm{x}$ proportion of the cost of share capital $)$

Cost of debt $(\mathrm{kd} *)=\mathrm{kd}(1-\mathrm{Tax})$

Cost of share capital $(\mathrm{ke})=\mathrm{krf}+(\mathrm{km}-\mathrm{krf}) \beta$

Description:

EVA $=$ Economic Value Added.

NOPAT $=$ Net Operating Profit After Taxes.

EBIT = Earnings Before Interest \& Taxes.

WACC $=$ Weighted Average Cost of Capital.

$\mathrm{krf}=$ risk-free interest rate as measured by the interest rate of Bank Indonesia Certificates (SBI).

$\mathrm{km}=$ rate of return expectations in the stock market.

$\beta=$ beta coefficient of stock that is used as an index of risk for the stock company.

\subsubsection{Shareholder Value (SV)}

Shareholder value is the creation of shareholder value. Shareholder value measured by the two approaches, namely the Market Value Added (MVA) and the Created Shareholder Value (CSV), as the dependent variable.

\subsubsection{Company Size}

Company size is a control variable in this study. The logarithm of the firm size measured by the total assets of the company. Firm size effect on firm value. The bigger the company, the greater the value of the company (Herawaty, 2008). Large companies tend to act fewer earnings management than smaller companies.

\subsubsection{Corporate Leverage}

Leverage the company is a control variable in this study. Leverage is total debt divided by total assets. According to the research and Machfoedz Siallagan (2006) in Rachmawati and Triatmoko (2007) stated that the leverage may reduce conflicts of interest between managers, owners, and bondholders. Companies that have substantial leverage may decrease firm value (Rachmawati and Triatmoko, 2007).

\subsection{Data Analysis Technique and Hypothesis Testing}

To test the hypothesis used regression analysis. Research hypotheses were tested using the equation:

$$
\text { MVAi,t }=a 0+a 1 E V A i, t+a 2 \log A S S T i, t+a 3 L E V i, t+\varepsilon i, t
$$


Description:

VMAs, $\mathrm{t}=$ Market Value Added (MVA) firm I in year $\mathrm{t}$.

$\mathrm{CSVi}, \mathrm{t}=$ Created Shareholder Value $(\mathrm{CSV})$ firm $\mathrm{i}$ in year $\mathrm{t}$.

a0 $=$ constant model

a1 $=$ EVA relevant measurement values.

EVAi, $=$ Economic Value Added firm $\mathrm{i}$ in year $\mathrm{t}$.

ASSTi,t = firm size measured by the logarithm of total assets at the firm $\mathrm{i}$ in year $\mathrm{t}$, is the control variable.

$\mathrm{LEVi, \textrm {t }}=$ firm leverage as measured by dividing total debt by total assets at the firm $\mathrm{i}$ in year $\mathrm{t}$, is the control variable.

$\varepsilon \mathrm{i}, \mathrm{t} \quad=$ residual error

\section{Results and Discussion}

\subsection{Data Collection}

The population in this study are all companies listed on the Stock Exchange. The sample is non-financial companies listed on the Stock Exchange for which data are available to calculate the variables tested in this study. The study period was from 2008 to 2012. Companies listed on the Stock Exchange during the year as many as 300 companies. Of the 300 listed companies, excluded from the sample of 50 derived from financial companies (banks, credit companies other than banks, securities firms and insurance companies). Of the 250 non-financial companies that made these samples, 10 firms or incomplete data are expressed in dollars, so it should be excluded from the sample. Thus used as samples in this study were 240 companies over 5 years of observation with a total of 1200 observations. Briefly, sample selection can be seen in Table 1 below:

Table 1. Selection of Study Sample

\begin{tabular}{|l|c|c|c|c|c|}
\hline \multicolumn{1}{|c|}{ Description } & \multicolumn{5}{|c|}{ Company Amount / Year } \\
\cline { 2 - 6 } & 2017 & 2016 & 2015 & 2014 & 2013 \\
\hline $\begin{array}{l}\text { Companies listed on the Stock } \\
\text { Exchange in 2013-2017 }\end{array}$ & 300 & 300 & 300 & 300 & 300 \\
\hline Finance company & $(50)$ & $(50)$ & $(50)$ & $(50)$ & $(50)$ \\
\hline $\begin{array}{l}\text { Companies for which data are } \\
\text { incomplete or expressed in dollars }\end{array}$ & $(10)$ & $(10)$ & $(10)$ & $(10)$ & $(10)$ \\
\hline The total company that sampled & 240 & 240 & 240 & 240 & 240 \\
\hline Total observations & 1200 & & & \\
\hline
\end{tabular}

\subsection{Descriptive Statistics}

Before testing the hypothesis it will be seen first descriptive statistics of each variable tested in this study. Descriptive statistics of variables that are the focus of this study is presented in table 2 below: 
Table 2. Descriptive Statistics

\begin{tabular}{|l|c|r|r|r|r|}
\hline Variable & N & Minimum & Maximum & \multicolumn{1}{c|}{ Mean } & \multicolumn{1}{c|}{$\begin{array}{c}\text { Deviation } \\
\text { Standard }\end{array}$} \\
\hline EVA & & $1689.13^{12}$ & $6644.10^{12}$ & $5995.10^{9}-$ & $2353.10^{11}$ \\
MVA & 1200 & $1680.10^{12}$ & $1149.10^{12}$ & $6180.10^{6}-$ & $8412.10^{10}$ \\
LOGASST & 1200 & 1506.869 \\
LEV & 1200 & 5,027 & 13,315 & 10,482 & 1,869 \\
& 1200 & 7,389 & 5037,053 & 12,735 & 196,298 \\
& & & & & \\
\hline
\end{tabular}

Table 2 above shows the mean value of EVA from the observed sample is 5995,109. EVA is the highest value while the lowest value is 6644.10 12-1689.1312 2353.1011 with a standard deviation. From these data shows that the lowest value of the company EVA is negative, indicating that the company has a total capital cost greater than the operating profit after tax, or in other words, companies can not create economic value-added.

The mean MVA of the sample being observed is $-6180,106$. MVA is the highest value while the lowest value is $1149.1012-1506.10128412 .1010$ with a standard deviation. Mean values marked with a negative MVA indicate that on average the observed sample has a total share capital is greater than the market value of company stock or in other words, an average of the observed sample can not create value for shareholders.

\subsection{Hypothesis Testing and Discussion}

Hypothesis testing is done by regression analysis. This result test aims to determine the level of statistical significance of each independent variable and the dependent variable. The summary results of regression testing can be seen in Table 3. The hypothesis of the study examined the effect of EVA on shareholder value as measured using the MVA and CSV. The hypothesis proposed is as follows:

Hypothesis 1: $\quad$ Economic Value Added (EVA) affect the Market Value Added (MVA)

Table 3. Hypothesis Testing Results

\begin{tabular}{|l|c|}
\hline \multicolumn{1}{|c|}{ Variable } & Model 1 \\
\hline Dependent Variable: & LogMVA \\
Independent Variable: & $\begin{array}{c}\text { Coefficient } \\
(\mathrm{t} \text { stat })\end{array}$ \\
\hline C & 6,749 \\
& $(12,260)^{*}$ \\
\hline LogEVA & 0,538 \\
& $(12,419)^{*}$ \\
\hline LogASST & 0,085 \\
\hline LogLEV & $(4,456)^{*}$ \\
\hline
\end{tabular}




\begin{tabular}{|l|c|}
\hline $\mathrm{R}^{2}$ & 0.385 \\
\hline Adjusted $\mathrm{R}^{2}$ & 0,381 \\
\hline $\mathrm{F}$ & 71,615 \\
\hline Sig. & 0,000 \\
\hline
\end{tabular}

Note: * significant $1 \%$, ** significant $5 \%$

Table 3 shows the regression results to test the research hypothesis. Value of $F$ test on a model for the dependent variable of 71.615 and 27.336 MVA for the dependent variable CSV with a p-value of 0.000 . This shows the relationship between the independent variable regression with the dependent variable, so it can be stated that there is a relationship between EVA regression with shareholder value as measured by MVA and CSV. R2 values conformity (Adjusted R2) of $38.1 \%$. This indicates that the shareholder value variable is measured by EVA explained by the independent variables of $53.8 \%$ while the rest is explained by other causes outside the model.

EVA's influence on shareholder value is statistically significant at alpha $1 \%$. This is demonstrated through the value $t$ and $t 12.4190 .0007 .330$ with significance. Coefficient EVA relationship with shareholder value is positive 0.538 and 0.401 for the MVA to CSV, meaning that every $1 \%$ increase in EVA. This suggests that the higher EVA is the higher shareholder value.

The above hypothesis testing indicates that the first hypothesis is supported by second hypothesis statistics. Where the higher value of EVA, also mean the higher shareholder value. The results of this study are consistent with Stern (2004) which states that EVA is a positive effect on MVA. Besides, this study also supports the findings Ghanbari and More (2007) which states that there is a positive influence between the EVA to the MVA, the results of their study supports the results of the research Stern Stewart Management Services as an institution that developed the measurement of EVA and MVA. These results indicate that the performance of either produced by the company will be captured by the market, so the market responded positively to the company's performance. This will make investors increasingly interested and believe in the company, so the company's share price rises and an increase in market value (market value) company, which may ultimately create value for shareholders, so there is a positive relationship between EVA with shareholder value.

Firm size as control variables measured through the logarithm of total assets has a significant and positive impact on shareholder value in the form of the regression model. This shows that the larger the company the greater shareholder value. These findings support research Herawaty (2008) which states that the larger the company, the greater the value of the company. While the company leverage as control variables in regression models is only a significant effect on shareholder value as measured by the method of MVA. The leverage coefficient shows a negative sign which means the greater the company's debts, the smaller shareholder value. These findings support the results of research Triatmoko and Rachmawati (2007) which states that companies that have substantial leverage may decrease firm value.

\section{Conclusion and Limitation}




\subsection{Conclusion}

The research aims to obtain empirical evidence of the Economic Value Added (EVA) affects shareholder value by the method of Market Value Added (MVA). Using sample in this study were non-financial companies listed on the Stock Exchange from 2013-2017. The results can be summarized as follows: There is evidence to support that the Economic Value Added (EVA) positive effect on shareholder value or in other words, the higher EVA is the higher shareholder value and leverage had a negative effect on shareholder value as measured using the method of MVA. This means that the greater the smaller the debt the company shareholder value.

\subsection{Limitation}

The research only controls the effects of firm size and debt. Influence the type of industry that also affects shareholder value has not been included in the model, so further research is expected to enter the variable type of industry and other variables that affect shareholder value.

\subsection{Research Implications and Suggestions}

For investors, the expected results of this research provide consideration in determining the estimated shareholder value created by the company. In addition, Indonesia also expected investors can know and use the calculation of shareholder value in addition to using the MVA method can also be calculated using the CSV.

\section{References}

1. V. S. M. Ali M Ghanbari, IUP J. Account. (2007)

2. L. Booth, in Present. Fed. Press "Creating Sharehold. Value" Conf. (1998)

3. E. F. Brigham and M. C. Ehrhardt., Financial Management: Theory and Practice, 11 th ed. (Thomson, South Western, 2005)

4. S. Chen and J. Dodd, J. Manag. Issues (2001)

5. P. Fernández, SSRN Electron. J. (2005)

6. P. Fernández, SSRN Electron. J. (2005)

7. I. Ghozali, Aplikasi Analisis Multivariate Dengan Program SPSS (Badan Penerbit Universitas Diponegoro, Semarang, 2009)

8. D. N. Gujarati, Basic Econometrics, 4th ed. (McGraw-Hill Companies, New York, 2005)

9. D. Irala and R. Reddy, PES Bus. Rev. (2006)

10. J. K. Kramer and J. R. Peters, J. Appl. Financ. 11, 41 (2001)

11. D. Kyriazis and C. Anastassis, Eur. Financ. Manag. (2007)

12. R. D. Laksana, H. Hersugondo, S. Wahyudi, and H. Muharam, J. Appl. Econ. Sci. (2017)

13. A. RACHMAWATI and H. TRIATMOKO, Simp. Nas. Akunt. X Makassar (2007)

14. D. V. Ramana, SSRN Electron. J. (2011)

15. C. A. Ramezani, L. Soenen, and A. Jung, Financ. Anal. J. (2002)

16. S. Riceman, S. Cahan, and M. Lal, Eur. Account. Rev. (2002) 
17. J. Stern, J. Appl. Corp. Financ. 16, 91 (2004) 